\title{
Game Theory And Competitive Strategy Transportasi Online (Grab And Gojek) Conventional And Sharia Economic Perspective
}

\author{
Muhammad Abdullah Amin Hasibuan \\ Universitas Islam Negeri Sumatera Utara \\ Jl. Willem Iskandar, Pasar V medan Estate Sumatera Utara \\ Email: abdullahaminhasibuan33@gmail.com
}

\begin{abstract}
ABSTRACK
In this discussion the problem is about game theory and competitive strategies from online transportation, namely Grab and Gojek to get customers amid the progress of information, transportation and communication, so that there will be an understanding of the second strategy of Transfortasi mode in the development activities in Indonesia. The methodology in this discussion is descriptive, which is one type of research whose purpose is to present a complete picture of social settings intended for exploration and clarification of a phenomenon or social reality studied, namely grab strategy and Gojek. After the review, it was found that basically the two Transfortasi online modes compete with each other but still prioritize excellent service in the form of ease of ordering, convenience in vehicles, applying cash and non-cash payments, and the most important is vehicle security. In terms of Islamic economic law the activities carried out by the two modes of Transfortasi are not prohibited because they do not violate the rules in the text and alhadist as long as the people associated with them comply with the rules set by the two service providers.
\end{abstract}

Keywords: Game Theory, Grab, Gojek, Islamic Ecomics, Convensional Economics.

\section{A. Introduction}

Today's modern era is marked by advances in information and technology as well as telecommunications where humans, more specifically the Muslim ummah, have been spoiled with super sophisticated telecommunication tools so that they have a positive impact on the lifestyle of today's society, including the Islamic ummah, although it is possible that it will still have a negative impact on society itself. 


\section{Game Theory And Competitive Strategy Transportasi Online (Grab And Gojek) Conventional And Sharia}

Economic Perspective Muhammad Abdullah Amin Hasibuan

One of the positive impacts of advances in information technology and telecommunications is that it makes it easier for every community to travel outside the house even though in Islam the provisions for leaving the house have rules as written in the Koran and the Hadith of the Prophet Muhammad.

The development of telecommunications in the form of android and iphone provides opportunities for people and companies to develop online transportation where ordering is made by using telecommunications technology that uses Android or iPhone and the like without having to stop by the side of the road or use your voice to order the tranfortasi.

Amazingly this transportation mode is developed with certain features that have been packaged in such a way as to track various types of services, both transportation services such as cars, motorbikes between documents, buying food and so on, making it easier for customers to make transactions without having to get tired there. come here even the super busy people are very efficient to use this tranfortasi mode, this is what is called online transportation.

Currently, there are two large companies that provide online transportation in Indonesia, namely PT Grab Indonesia and PT Gojek Indonesia, where each of these companies has developed its business expansion efforts to make it easier for the public, including Muslims, to enjoy various convenience features for making transactions in every transportation activity. done by the community.

Various game theory models and competitive strategies carried out by PT Grab Indonesia and PT Gojek Indonesia will be discussed in this paper which will try to elaborate according to conventional economics and Islamic economics.

\section{B. Theory Study}

In this discussion, we will define:

a. Game theory is a part of science that deals with making decisions when two or more parties are in a state of competition or conflict. The competing parties are assumed to be rational and intelligent, meaning that each party will carry out a rational action strategy to win the competition, and each party also knows the strategy of the other party. Hereinafter this party is called a player. ${ }^{1}$ According to Ayu, game theory is a mathematical approach to formulate situations of competition and conflict between various interests. Game theory involves two or

1 Dimyati TT and Dimyati A. Operation Research: Models of Decision Making, (Bandung: CV. Sinar Baru Bandung: 1992), p. 75. 
more decision makers or so-called players. Every player in game theory has the desire to win. ${ }^{2}$

b. Competitive Strategy or competitive advantage is the ability obtained through the characteristics and resources of a company to have a higher performance than other companies in the same industry or market. There are several explanations by experts about Competitive Strategy, including: According to Kotler and Gary Armstrong competitive advantage or competitive advantage is an advantage over competitors obtained by offering lower value or by providing greater benefits because the price is higher. The use of this theory must be able to consider what aspects will be offered with low value but get greater benefits. For example, offering a low registration fee, but the program implemented is still good, maybe even the same as an expensive program. The role of competitive advantage is very important in company performance. Competitive advantage comes from the many activities of the company in designing, producing, marketing, delivering and supporting the products or services produced. 3 Porter explained that competitive advantages consist of: First, Low Cost (Low Cost), namely a strategy that relies on relatively low cost advantages in producing goods and services. Second, differentiation, namely the ability to produce goods and services that are unique and have more value in the form of quality, special characteristics and other services. Third, Focus, namely a strategy that seeks to excel in certain target segments. 4 Based on the above understanding, competitive advantage cannot be understood by looking at the company as a whole. Competitive advantage comes from the many different activities that companies carry out in designing, producing, marketing, delivering, supporting their products. Each of these activities can support a firm's relative cost position and create a basis for differentiation. For example, the cost advantage in a company can come from a low cost-based marketing system, effective and efficient operational activities, purchasing of high quality raw materials, and superior product design.

c. Online transportation is a transportation company that uses an application as a liaison between the user and the driver which makes ordering very easy,

${ }_{2}$ Media Ayu Anugrah,.Pengantar Research Operational, (Jakarta: Rineka Cipta, 1996), p. 70

3 Kotler, Philip dan Armstrong, Gary, Principles of Marketing. (New Jersey: Prentice Hall, 2012), p. 35 .

4 Ibid. 


\section{Game Theory And Competitive Strategy Transportasi Online (Grab And Gojek) Conventional And Sharia} Economic Perspective Muhammad Abdullah Amin Hasibuan

besides that the travel rates can be seen directly on the application. Another definition was mentioned by Doni from Unair who said that online transportation is a form of road traffic and transportation that runs by following and utilizing the development of science (technology). Another thing was also mentioned by Ellen from Unair who stated that online transportation is a form of developing the potential and role of national transportation which simultaneously supports economic development and regional development. From various explanations regarding online transportation that has mushroomed in this country, it can be concluded that the meaning of online transportation is an implementation of Road Traffic and Transportation that runs by following and utilizing the development of application-based and online science (technology) both for ordering and payment. 5

d. Perspective is a point of view or point of view of seeing the symptoms of a situation in the midst of society. In line with the various opinions put forward by experts such as Martono who state that perspective is a way of looking at a problem that occurs, or a certain point of view used to see phenomena as well as Ardianto and Q anes which interpret perspective as our point of view of seeing something. ${ }^{6}$

e. Conventional Economy is an economic system in the activities of human behavior in meeting their unlimited needs using limited production factors. 7

f. Sharia economics is a system in human activities related to production, distribution, exchange and acquisition and consumption of goods and services inspired by Islamic values. ${ }^{8}$

\section{Methodology}

The research methodology is carried out in a descriptive way, which is one type of research whose purpose is to present a complete picture of the social setting or is intended for exploration and clarification of a phenomenon or social reality, 9 by describing a number of variables with respect to the problem and the unit under study

\footnotetext{
${ }^{6} \mathrm{http}: / /$ www.definisimenurutparaahli.com/pengertian-perspektif-atau-sudutpandang/Accesed Thursday, 28 Februari 2019

7http://alihanafiah89.blogspot.com/2010/05/definisi-ekonomi-konvensional.html, Accesed Thursday,28 Februari 2019

8http://ilmuekonomis.blogspot.com/2015/02/pengertian-ekonomi-konvensionaldan.html, Accesed Thursday, tanggal 28 Februari 2019.

9Penelitian Deskriptif. Accesed Thursday, 28 Februari 2019.
}

5https://belajarpsikologi.com/pengertian-transportasi-online/Accesed Thursday, 28 Februari 2019. 
between the phenomena being tested. . In this study, the researcher has a clear definition of the research subject and will use the who question to dig up the information needed.

\section{Findings}

From the observations made, there are several findings that can be written as follows:

a. That online transportation is very loved by the community, this can be seen from the number of orders made by customers to grabs totaling 2.5 million subscribers every day. ${ }^{10}$ Likewise with motorbikes which receive orders of more than 100 million each month. ${ }^{11}$

b. That online transportation is spreading, where this can be seen on the streets where a lot of people use this transportation mode, as well as the number of drivers who spill over in big cities in Indonesia and in Southeast Asia.

c. The number of features in ordering in online transportation makes this transportation mode an idol in the midst of society.

d. Competitive and relatively affordable prices make online transportation very loved.

e. How to order that is easy to do even if you don't have an application or Android, iPhone and internet data packages, many customers who order through friends or relatives and even people around us make this transportation mode easy to use.

f. Payment of tariffs can be made in cash and non-cash if in cash it is made by payment with a valid currency of exchange in the form of money while in noncash, namely by using grap pay or OVO or Gopay, which is a type of electronic money that is easier to use without having to pay and ask for change when have arrived at the destination or at the time of making a payment.

\section{E. Discussion}

a. Online Tranfortasi Strategy

Who doesn't know this application service-based company? An online transportation that has become a basic necessity in metropolitan cities and several

${ }^{10} \mathrm{https}$ //www.grab.com/id/press/business/grab-rayakan-ulang-tahun-ke-5-danpencapaian-signifikan-pengguna/, Accesed Thursday, 28 Februari 2019

${ }^{11}$ https://tekno.kompas.com/read/2017/12/18/07092867/berapa-jumlah-penggunadan-pengemudi-go-jek., Accesed Thursday, 28 Februari 2019 


\section{Game Theory And Competitive Strategy Transportasi Online (Grab And Gojek) Conventional And Sharia}

Economic Perspective

Muhammad Abdullah Amin Hasibuan

other big cities. That's right, online motorcycle taxis are a booming transportation service right now.

Although in recent times, this online-based transportation has received a big challenge in the form of pros and cons that occurred when the local government revoked the service operating license. However, all these obstacles actually make online transportation more successful, and it can even become a basic necessity in big cities, like Indonesia.

There are two points to highlight here. First, the mistakes of public transportation-based companies that ultimately make the market switch to online transportation services. If you look deeper, the root of the problem lies in the old Marketing Strategy which is being maintained. Whereas entrepreneurs fail due to businessmen who insist on the old strategy that does not bring results for the company. This is what has happened to several public transport service providers or the taxi industry which has been displaced due to online transportation. It must be admitted that we have entered the era of the global economy like today, anyone can enter with various business models run by everyone. Especially internet-based businesses and technology are starting to arrive. Finally, this condition makes consumers increasingly accustomed to brilliant business ideas carried out by several people and that is what they are waiting for.

The second aspect is that the advantages that we can learn from online transportation services such as Gojek and Grab or other online businesses are how the business model that is run can be accepted by the community and adapt to the times. In this case, the service provider company, everything is completely connected to the internet.

Then the strategies they use so that the online business they run can be successful at least 5 accurate strategies in running a business. namely:

1. Prioritizing Customers, Today's business people have succeeded in guessing the market's willingness and want to understand that customers are not only limited to buyers. In the past, only business people. Behave both the buyer and if they do not buy impress indifferent and unfriendly. Well, now everything has changed. Business people, especially online transportation, mean that the customer is a colleague, team or even king. Because of this, business people must really focus on customers and the general public who use services. They also have to realize that the market wants them to be the priority and scale of the company's needs. At least, this is what online transportation service providers such as Gojek, Grab and Uber 
are doing in seeing the current market conditions. So far, maybe a lot of customers spend their time waiting for transportation to arrive, or they take public transportation with drivers who are not friendly, inconsiderate and customers do not feel comfortable at all. True, many customers have been disappointed.

2. Definite price, if you look at the progress of cyber business people, it is more due to the success of providing clear, definite information and customers already know the price from the start. So, they no longer feel nervous about the price given because it is clear. Of course, from this we already know that people in the digital era have made observations before making a transaction. So the main thing that is needed is the validity of the price of a product and of course without any defects as they ask for.

3. Focus on Improvement, The success of online transportation in capturing the market is something that we should appreciate. Although in several cities, onlinebased services are opposed, online transportation has spread to all sectors. Even some companies like Gojek do not only provide delivery services. However, it has provided solutions for citizens of Indonesia and several other cities. Imagine, as many as 10 million people have downloaded and enjoyed the services they provide. It can be said that the startup entrepreneur founded by Nadiem Makarim is the largest startup in Indonesia. Even in the repair process, Gojek has provided 15 services, from Go-Ride, Go-Car, Go-Food, Go-Send, Go-Mart, Go-Box, Go-Massage, Go-Clean, Go-Glam, Go-Tix, Go-Busway, Go-Pay, Go-Med, Go-Auto and most recently Go-Pulsa. Well, the result of this continuous improvement. Online-based companies have succeeded in increasing their competitiveness and leaving conventional business patterns that are obsolete.

4. Sensitive to Market Needs, Sensitive to market needs and the current situation are indispensable things in building a business. In this case, the business owner has an important role in determining the direction of the company. So he must prove that he is able to bring the company to move in a more significant direction. You can also see that application businesses such as Gojek, Grab and Uber are businesses that have been tested to create jobs, absorb new workers and become smart solutions to current conditions.

5. The pursuit of perfection, that a company should not be too rigid with a business approach, "once independent remains independent." It can't be like that. Because in the current era, the market continues to change and online-based businesses have been very aggressively developing. Now, if we are slow in pursuing perfection, then 


\section{Game Theory And Competitive Strategy Transportasi Online (Grab And Gojek) Conventional And Sharia}

Economic Perspective

Muhammad Abdullah Amin Hasibuan

we will be left behind. Updating and perfecting a business must be done every time, so that you can create a new trend and pattern in people's consumption. Online transportation can be said to be successful in introducing new business models by combining technology and innovative business models. For customers who use online application-based transportation services, it means that they have considered convenience compared to using public transportation or base motorcycle taxis, which sometimes make customers wait and even get disappointed with the service. Meanwhile, for some industries, entering the global era with increasingly sophisticated technology and easy internet services, they must be able to change their old mindset and marketing strategy. This is the right choice compared to sticking with the old patterns or ways.

\section{b. Grab strategy to get customers}

After Grab acquired Uber, the online transportation service provider only had to compete with Go-Jek in Indonesia. The intense competition between companies forces both parties to create new innovations in order to attract many customers.

At the age of six, the CEO of Grab launched GrabPlatform as the new face of this Southeast Asia-based application. Later, Grab will provide services between large quantities of groceries, presenting the latest news, to game features.

This competition will give birth to new innovations so that they will appear better. Want to know what innovations and strategies are used by Grab to compete with other competitors, including:

a) Launched GrabPlatform, an all-featured application , Carrying the spirit of Everday Superapp, GrabPlatform is committed to being an application that helps daily activities. With just one application, Grab users can do whatever they want. With GrabPlatform, people can people can book transfortasi cars, motorcycles, also can order food, read the news, play games, and even that could be a wallet because it is filled with electronic money that can be used to shop at the outlets outlets have been using OVO . Everything is just one application .

b) Embracing start-ups to grow rapidly. Currently, Grab has recorded two billion drivers with 100 million downloads and has spread across eight countries. With its network, Grab is open to start-ups who want to work together. This step is one of Grab's strategies to compete with other competitors, including Go-Jek.

c) Fast and easy disbursement of money for drivers. Not only is the feature enhanced by Grab, their attention to drivers is also increased. Such as the process of fast instant disbursement of funds for those who are paid non-cash. As Ceo Grab stated, "We 
understand that many driver-partners are still reluctant to accept cashless payments due to the longer processing times for credit and debit card transactions. We believe this instant disbursement feature will make them more comfortable with non-cash payments, "explained Mediko Azwar as Marketing Director of Grab Indonesia. In other words, it doesn't take drivers days to cash out payments via GrabPay or OVO.

d) SOS button for emergency situations for passengers . Regarding the rampant crime committed by unscrupulous Grab drivers, the management has added an SOS button to improve passenger safety. With just two touches, the passenger's last location will automatically be spread to friends or family members. Then, Grab also implemented a Know Your Driver-Partners (KYP) policy as a condition for registering as a driver. With KYP, drivers are required to submit their KTP, SIM, STNK, and Police Record Certificate (SKCK). ${ }^{12}$

\section{G. Gojek Strategy to Get Costumers}

Go-Jek Indonesia is a transportation service in Indonesia that has been operating since 2011. Go-Jek is the pioneer in providing professional motorcycle taxi services. Trying to offer the factors of speed, safety and convenience for its customers, Go-Jek is growing as a promising startup in the capital. To reduce the problem of providing cash, Go-Jek offers Go-Jek Credit e-wallet solutions. You could say Go-Jek is like a motorcycle taxi version of Uber which is suitable for delivering goods, means of transportation, and even helping with shopping activities in the Indonesian wilderness .

In terms of attracting consumers, Go-Jek implements a variety of marketing strategies including:

a) One of them is in determining the tariff. Pricing activities play an important role in the marketing mix process. Pricing decisions are very important in determining how far a service is valued by consumers and the image building process. Pricing also provides certain perceptions in terms of quality. In this case Go-Jek sets a fairly cheap rate for its service users so that consumers who used to use regular motorbikes then switch to Go-Jek.

b) Strategy in the promotion of services. Such as the establishment of advertising media using internet, social media, brochures, radio, direct selling, events, media partners, and also through traditional marketing such as word of mouth publications. Go-Jek itself is also very familiar among artists, so in this case Go-jek also uses artists as brand ambassadors to attract consumers.

${ }^{12 h t t p s: / / w w w . i d n t i m e s . c o m / n e w s / i n d o n e s i a / v a n n y-r a h m a n / b e r s a i n g-k e t a t-d e n g a n-~}$ go-jek-ini-4-jurus-ampuh-grab/full, Accesed Thusrday, 28 Februari 2019. 


\section{Game Theory And Competitive Strategy Transportasi Online (Grab And Gojek) Conventional And Sharia}

Economic Perspective Muhammad Abdullah Amin Hasibuan

c) Making various kinds of feedback received, Go-Jek provides many benefits for consumers seen from the various service features offered by Go-Jek such as GOSEND, GO-RIDE, GO-FOOD, GO-MART, GO-BUSWAY, GO-BOX, GO-CLEAN, GO-GLAM, GO-MESSAGE, can be said to spoil consumers.

\section{F. Perspective of Conventional Economics and Islamic Economics}

a) Conventional Economic Perspective

Conventional Economy is a model of economic activity used in Indonesia today, seeing the business strategy carried out by Grab and Gojek as two online transportation modes in Indonesia, so the strategy used is an effort to attract consumers to use their services.

In terms of the effort made, of course it has a minius plus for service users if convenience is a priority scale, it depends on the service provider itself. In Indonesia, an online transportation driver is free and can use 2 applications at the same time with the same transportation mode even though in terms of permits it is not played by companies, either Grab or Gojek. So in terms of relative convenience, vehicles provide convenience for customers.

That the conventional economy has the concept of getting the greatest possible profit as an economic motive even though it is without limits, it must see competition and competitive opponents so that it is necessary to take measurements by looking at the platforms made by their opponents.

Conventional economic ethics allows and approves all strategic platforms created by online transportation, both grab and Gojek, as long as the platform can provide benefits or provide cash, conventional allows it. In principle, if the service is sold in accordance with the terms of the price offered, conventionally guarantees it.

\section{b) Islamic Economic Perspective}

Sharia economics is an economic principle based on the Koran and the hadith of the prophet Muhammad SAW, in fact every transaction or economic activity in any form should not deviate from the rules of Allah SWT as written in the text of the Koran and al hadith.

The concept of Game theory and Competitive strategy carried out by the online transportation mode is currently part of muamalah, if it is seen from the perspective of Islamic economic law that the legal basis of muamalah is permissible unless there are arguments against it.

As long as this form of transaction does not violate the concept of Maghrib (Maisir, Gharar, Riba) and other matters that have been regulated in Nash, so long as 
this form of competition from the second mode of online translation is allowed in the review of Islamic economic law.

There are several forms of strategy carried out by these two modes of transportation which we can explain the laws according to the findings we find in online transportation activities as follows :

1. That online transportation is very loved by the public, this can be seen from the number of orders made by customers to grabs totaling 2.5 million subscribers every day. ${ }^{13}$ Likewise with motorbikes, which receive orders of more than 100 million each month. The explanation of this from a legal point of view is that it is permissible for every milk as long as there is no argument against it.

2. That online transportation is spreading, where this can be seen on the streets where a lot of people use this transportation mode, as well as the number of drivers who spill over in big cities in Indonesia and in Southeast Asia,

3. The number of features in ordering in online transportation makes this transportation mode an idol in the midst of society. As long as this feature does not contain immorality, it is possible that at this time there are features that may need to be legally emphasized, namely the Go massage feature or ordering for massage or poke. In Islam, it does not regulate the thread or sequence, but in Islam what is allowed is cupping where cupping is part of the treatment of the Prophet Muhammad.

4. Competitive and relatively affordable prices make online transportation very loved. Understanding the wishes of customers is part of creativity, Islam respects creativity because in the Koran it is stated as follows:

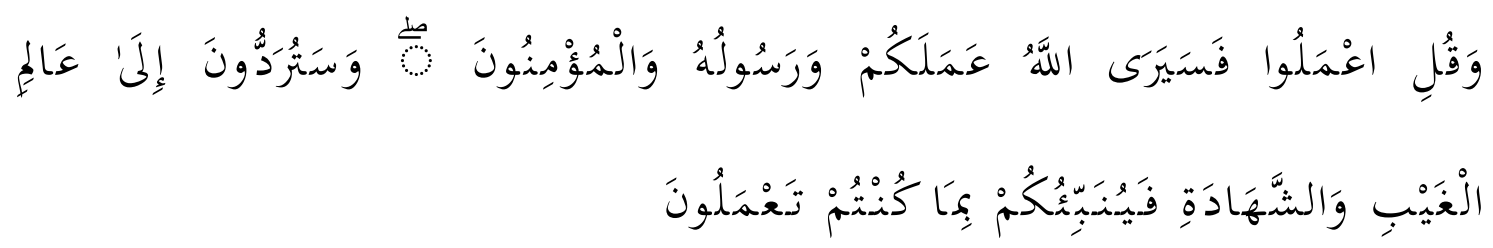

And Say: "Work you, then Allah and His Messenger and the believers will see your work, and you will be returned to (Allah) Who Knows the unseen and the real, and He will tell you what you have done. do it. ${ }^{14}$

How to order that is easy to do even if you don't have an application or Android, iPhone and internet data packages, many customers who order through friends or

${ }^{13}$ https://www.grab.com/id/press/business/grab-rayakan-ulang-tahun-ke-5-danpencapaian-signifikan-pengguna/ Accesed Thursday, 18 Februari 2019.

${ }^{14}$ Alquran surah 9 (Attaubah) ayat 105. 


\section{Game Theory And Competitive Strategy Transportasi Online (Grab And Gojek) Conventional And Sharia} Economic Perspective Muhammad Abdullah Amin Hasibuan

relatives and even people around us make this transportation mode easy to use. In Islam the concept of help as a Muslim identity is recommended as Allah says:

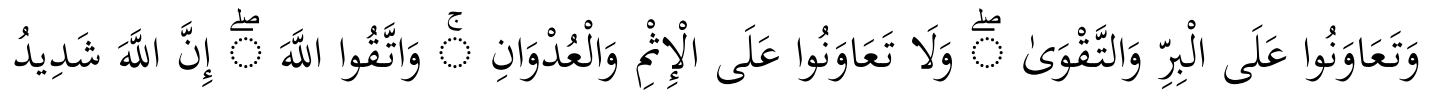

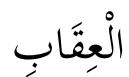

And help you in (doing) goodness and piety, and don't help in committing sins and transgressions. And fear Allah, indeed Allah is very heavy in punishment. ${ }^{15}$

Payment of tariffs can be made in cash and non-cash if in cash it is made by payment with a valid currency of exchange in the form of money while non-cash is by using GRAB PAY or OVO or GOPAY, which is a type of electronic money that is easier to use without having to pay and ask for change when have arrived at the destination or at the time of making a payment. The Islamic economic perspective allows this transportation model both in terms of transportation mode and buying and selling transaction model. Many people doubt the use of non-cash payments which are cheaper than cash, but in Islam this is permitted by means of buying and selling greetings. A salam card is a transaction using cash paid for in cash, goods will follow. However, the object of the Salam contract transaction is goods. Consumers buy goods, the money is paid in cash up front, but the goods arrive a month or two later.

Our people do a lot of these transactions, such as e-Toll or e-money for payment of some services provided by application organizers. The contract is a sale and purchase, with money being paid up front, while the benefits / services will only be obtained after a few days or a few days later. Ibnul Mundzir said, 'The scholars I know agree that the legal greeting is acceptable.' Because goods are one of the objects of the transaction, they may be deferred as payment. As this applies to goods, this also applies to services. So it is okay for consumers who have credit to Gopay on motorbikes and Ovo on Grab to get a discount. ${ }^{16}$

\section{F. Conclusion}

That the Theory game which is carried out by Grab and Gojek as an Online Transportation Mode currently tends to be the same, namely prioritizing convenience

${ }^{15}$ Alquran Surah 5 (al Maidah) ayat 2

${ }^{16}$ https://islampedia.id/apakah-riba-jika-menggunakan-fitur-go-pay-dari-go-jekacac1b7ce912, accesed Thursday, 28 Februari 2018. 
for customers, providing security for passengers and excellent service for customers in accordance with the operational standards of their respective companies.

Whereas the competitive strategy used is kneeling on adding features to the convenience of ordering features, the number of menus in the application so that companies not only benefit from transportation activities but also from other features provided in the application.

Fare payments made by passengers through electronic money transactions in the form of OVO or GOPAY make it easy for passengers so that passengers and drivers do not have to look for change, they must exchange money as is done when the transaction uses cash.

In Islamic law, the activities carried out by these two modes of transformation are allowed as long as there are no texts that prohibit it, in fact, no transactions are prohibited as long as all parties obey the rules set by the application provider, namely the grab party and the Gocar party.

\section{G. Reference}

Alquran al Karim, tafsirq.com .

Dimyati TT and Dimyati A. Operation Research: Retrieval Models Decision , Bandung: CV. Sinar Baru Bandung: 1992.

Media Ayu Anugrah, Introduction to Research Operationa, Jakarta: Rineka Cipta, 1996.

Kotler, Philip and Armstrong, Gary, Principles of Marketing . New Jersey: Prentice Hall, 2012 .

https://belajarpsikologi.com/pengentuk-transportasi-online/ accessed on Thursday, February 28th, 2019.

http://www.ddefineimenurutparaahli.com/pengentuk-perspektif-atau-sudut pandang, Thursday, February 28, 2019.

http://alihanafiah89.blogspot.com/2010/05/definisi-ekonomikonvensional.html, Thursday, February 28th, 2019 


\section{Game Theory And Competitive Strategy Transportasi Online (Grab And Gojek) Conventional And Sharia}

http://ilmuekonomis.blogspot.com/2015/02/pengentuk-ekonomi-konvensionaldan.html , Thursday, February 28, 2019

Descriptive Research . Accessed February 28, 2019.

https://www.grab.com/id/press/business/grab-rayakan-ulang-tahun-ke-5-danpencapai-signifikan-pengguna/ , Thursday 28th Fenruari 2019

https://tekno.kompas.com/read/2017/12/18/o7092867/berapa-jotal-pengguna-danpengenger-go-jek ., Thursday February 28, 2019

https://www.idntimes.com/news/indonesia/vanny-rahman/bersaing-ketat-dengango-jek-ini-4-jurus-ampuh-grab/full , Thursday, February 28, 2019.

https://www.grab.com/id/press/business/grab-rayakan-ulang-tahun-ke-5-danpencapai-signifikan-pengguna/

https://islampedia.id/apakah-riba-jika-mengusing-fitur-go-pay-dari-go-jekacac1b7ce912 , Accessed February 28, 2019. 